\title{
Technical Note: \\ A comparison of techniques for extracting monoterpenoids from Juniperus (Cupressaceae) species
}

\author{
M. K. OWENS, E. J. STRAKA, C.J. CARROLL, AND C.A. TAYLOR, JR.
}

Authors are associate professor, research associate, research technician, and professor, respectively, with the Texas Agricultural Experiment Station. MKO
and CJC are located at 1619 Garner Field Rd, Uvalde, Tex. 78801 and ESS and CAT are located at the Sonora Research Station, PO Box 918, Sonora, Tex 76950 .

\begin{abstract}
Concentration and composition of monoterpenoids in plant tissue affects a variety of environmental and ecological issues such as plant defenses, plant classification, and phytotoxicity. Developing the techniques for extracting and estimating the concentration and composition of monoterpenoids must be speciesspecific because monoterpenoid storage location varies between species. Ashe juniper (Juniperus ashei Buchholz) and redberry juniper ( $J$. pinchotii Sudw) are 2 co-occurring species which differ in palatability and preference. The objective of this study was to determine which of 2 common extraction techniques provided the best estimate of the concentration and composition of monoterpenoids in mature plant tissue. Two extraction techniques were tested by soaking crushed juniper needles in hexane solvent for $6,12,18$ and 24 hours or by steam distilling samples for $2,4,6$, or 8 hours. The extracts were analyzed by using 2 different analytical columns in separate gas chromatographs. The hexane solvent soak, regardless of time in the solvent, yielded a lower total concentration and a decreased compositional diversity of monoterpenoids compared to the steam distillation technique. An 8-hour steam distillation yielded the greatest concentration and composition of monoterpenoids. Both types of analytical columns resulted in similar estimates of monoterpenoid concentrations and composition.
\end{abstract}

Key Words: redberry juniper, Ashe juniper, steam distillation, solvent soak, gas chromatography, terpenes

Plant phytochemicals play an important ecological role in plant defenses (Bryant et al. 1991), plant classification (Adams and Kistler 1991, Adams 1994), plant palatability (Bray et al.1991, Riddle et al. 1996), phytotoxicity (Wilt et al. 1993, Tarayre et al. 1995) and perhaps in fire ecology (Philpot and Mutch 1968, White 1994). One of the major groups of phytochemicals are monoterpenoids but estimating the amount and composition of monoterpenoids can be problematic (Muzika et al. 1990). The problem lies in efficiently extracting monoterpenoids from leaf tissue and in making repeatable estimates of the concentration and composition of monoterpenoids.

Research was funded in part by USDA Rangelands Competitive Grant 9203917 Manuscript accepted 20 Jan. 1998.
The simplest extraction technique is a solvent soaking where 2 to $10 \mathrm{~g}$ of fresh leaf material is placed in pentane or hexane (Wilt et al. 1993, Gambliel and Cates 1995, Zou and Cates 1995) for as little as 15 minutes (Kainulainen et al. 1992) or as long as 48 hours (Hall and Langenheim 1986) depending on the plant species and sample preparation. Another extraction technique frequently reported in the literature is a steam distillation process where fresh leaf material is steam-extracted into hexane or pentane (Muzika et al. 1990, Riddle et al. 1996). The steam distillation process can last as little as 90 minutes (Hachey and Simard 1987) or as long as 8 hours (Muzika et al. 1990). A survey of the literature shows that both extraction techniques are used in about equal frequency across a wide array of species (Hachey and Simard 1987, Gilmore 1977, Chang and Hanover 1991, Muzika et al. 1989).

Accurate estimation of monoterpenoids depends on the use of a gas chromatograph (GC). There are many different types of GC's and different analytical columns for detecting natural compounds. Column length, internal bore, and film thickness affect the length of time a compound is retained in the column, and can affect the accurate detection of monoterpenoids.

The objectives of the current study were to determine: 1 ) which extraction technique was most complete in terms of concentration and composition of individual monoterpenoids in Ashe juniper (Juniperus ashei Buchholz) and redberry juniper (J. pinchotii Sudw) foliage; 2) how the length of time in the extraction process affected the concentration and composition of monoterpenoids; and 3 ) how the analytical process (2 different types of GC's and columns) affected the concentration and composition estimates of monoterpenoids.

\section{Methods}

The study was conducted using Ashe juniper (other common names include mountain cedar, post cedar and blueberry juniper) and redberry juniper populations from the Edwards Plateau region of central Texas. Ashe juniper is a dioecious tree or shrub ranging in size from 1 to $6 \mathrm{~m}$ at maturity, with a single main stem, and a globular or irregular growth form. Ashe juniper usually grows on calcareous soils and rocky slopes of southern Oklahoma, central Texas and northern Mexico. Redberry juniper is also a dioecious species, has multiple main stems, and sprouts readily from the base after disturbance. Redberry juniper grows 
mainly on gravelly, rocky soils of central Texas. Field samples were collected at the Sonora Research Station in central Texas $\left(31^{\circ} \mathrm{N}, 100^{\circ} \mathrm{W}\right.$, elevation $\left.=732 \mathrm{~m}\right)$.

Ten mature trees of each species were subjectively selected on the Sonora Station in May 1993. Fifty $g$ of leaf and small stem tissue were collected from each tree, divided into 2 aliquots, and placed into liquid nitrogen to halt physiological activity and prevent volatilization of monoterpenoids. One aliquot was kept at the Sonora Station for analysis and the other was transported to the Uvalde Research and Extension Center for analysis. Samples were stored in plastic bottles with airtight caps at $-80^{\circ} \mathrm{C}$ in an ultracold freezer until analysis.

Two techniques were used to extract monoterpenoids from the leaf samples at both laboratory locations. The first technique was a simple hexane soak where $2 \mathrm{~g}$ of frozen leaf material was ground in a mortar and pestle filled with liquid nitrogen and placed in $10 \mathrm{ml}$ of hexane at room temperature. The beaker was covered with Parafilm to prevent evaporation of the hexane and $10 \mu \mathrm{l}$ of tetradecane was added as an internal standard. Samples were withdrawn from the soaking solution after $6,12,18$, and 24 hours to test the effect of the length of time in the soaking process. The second technique was a steam distillation with a volatile oil distillation trap (VWR Scientific). Five $\mathrm{g}$ of frozen leaf material was ground in liquid nitrogen, placed in a beaker with $150 \mathrm{ml}$ of distilled water, and steam distilled into $5 \mu \mathrm{l}$ of hexane. Samples were withdrawn after 2, 4, 6, and 8 hours. Five $\mu \mathrm{l}$ of tetradecane was added as an internal standard. Although different weights of leaf samples were used in the 2 techniques ( 2 vs $5 \mathrm{~g}$ ), the concentration of oils ( $\mathrm{mg} \mathrm{g}^{-1}$ fresh weight) could be directly compared.

Monoterpenoid composition and concentration were estimated with 2 different gas chromatography (GC) systems. The Uvalde location used an HP 5890 GC equipped with a $0.25 \mathrm{~mm} \times 25 \mathrm{~m}$ fused silica capillary column. Helium was used as the carrier gas. The temperature program was $70^{\circ} \mathrm{C}$ for 2 minutes, a $1.5^{\circ} \mathrm{C}$ per minute increase to $97^{\circ} \mathrm{C}$, a $6^{\circ} \mathrm{C}$ per minute increase to $187^{\circ} \mathrm{C}$ and then a $15^{\circ} \mathrm{C}$ per minute increase to $262^{\circ} \mathrm{C}$. The injection port temperature was $280^{\circ} \mathrm{C}$ and detector temperature was $240^{\circ} \mathrm{C}$. Data were output directly to a computer with data acquisition software. The Sonora location used an HP5790A GC equipped with a Megabore HP-5 crosslinked 5\% phenylmethyl silicose colurnn (30 $\mathrm{m} \times .53 \mathrm{~mm} \times 2.65 \mu \mathrm{m}$ film thickness). The same temperature program was used in both locations. Helium carrier gas was maintained at a flow rate of $6.5 \mathrm{ml} \mathrm{min}$. Injector port temperature was $280^{\circ} \mathrm{C}$ and the detector temperature was $240^{\circ} \mathrm{C}$. Peak areas were measured with a HP3394 integrator. Terpenes were identified in both laboratories by comparison to external standards.

Data were expressed on a fresh weight basis to remain consistent with published literature and were analyzed in 2 separate steps. Average percent dry matter of the Ashe juniper samples was $53 \%$ and of redberry juniper was $55 \%$. The first analysis used the total amount of monoterpenoids as the dependent variable in a split-plot, repeated measures analysis of variance. Main factors included tree (as replication), extraction technique, plant species, and the extraction technique by plant species interaction. The tree-by-extraction technique-by-plant species interaction was used as the error term. Type of analytical column was analyzed in the split-plot including all 2-way interactions with the main effects. Length of the extraction process was the repeated factor.
All tests were conducted using $p<0.05$. The second analysis was designed to evaluate the effects of the extraction techniques on the concentration of individual monoterpenoids. The statistical model was the same as the one used in the first analysis, but the dependent variable was the concentration of each individual monoterpenoid. A sphericity test was conducted for each analysis to determine the most appropriate error matrix (von Edne 1993). If Mauchley's criterion was not significant, univariate tests were used, otherwise multivariate test results were used (SAS 1988)

\section{Results}

\section{Comparison of Extraction Techniques}

Steam distillation yielded a greater concentration of total monoterpenoids than a simple hexane soak $(F=147.4$, $\mathrm{df}=1,12)$. Mean concentration of monoterpenoids in Ashe juniper was $11.41 \mathrm{mg} \mathrm{g}^{-1}$ of fresh foliage ( $\mathrm{SE}=1.16$ ) when extracted via steam distillation but only $5.90 \mathrm{mg} \mathrm{g}^{-1}(\mathrm{SE}=1.07)$ when extracted with a hexane soak. A similar pattern in concentrations was detected in redberry juniper where $10.05 \mathrm{mg} \mathrm{g}^{-1}$ of fresh foliage $(\mathrm{SE}=0.53$ ) were extracted via steam distillation, but only 4.81 $\mathrm{mg} \mathrm{g}^{-1}(\mathrm{SE}=0.80)$ via solvent extraction. There were no other significant effects between the 2 species or the GC columns in total monoterpenoid concentration.

Eighteen different monoterpenes were identified in these 2 species of juniper (Table 1). Fifteen were affected by the extraction technique with the steam distillation technique yielding the greater diversity of monoterpenoids. The concentrations of only 3 monoterpenoids ( $\alpha$-pinene, $\beta$-pinene and linalool) were similar between the extraction techniques. These monoterpenoids were minor components, with concentrations typically $<0.1 \mathrm{mg} \mathrm{g}^{-1}$ fresh needle weight. The most abundant monoterpenes were camphor, limonene, and sabinene. These 3 compounds accounted for 64 and $53 \%$ of the total concentration of monoterpenoids extracted by steam distillation in Ashe and redberry juniper, respectively. These same 3 monoterpenoids accounted for 98 and $79 \%$ of the total concentrations extracted by the hexane soak in Ashe and redberry juniper, respectively, suggesting that many of the minor monoterpenoids were not being extracted by the hexane solvent soak.

\section{Effect of Time}

The amount of time the sample remained in the extraction process significantly affected the total concentration of monoterpenoids detected $(\mathrm{F}=29.7, \mathrm{df}=3,39$ ). The interaction between the length of time in the extraction process and the extraction technique was also highly significant $(F=10.9$, $\mathrm{df}=3,39)$. Only slight increases in the total concentration of monoterpenoids were detected with longer soaking times in the hexane treatment, but concentrations increased rapidly with time in the steam distillation technique (Fig. 1). The concentrations of individual monoterpenoids ( $\alpha$-pinene, bornyl acetate, camphene, $\gamma$-terpinene, limonene, myrcene, sabinene, terpineol, terpine-4-ol, and tricyclene) increased only slightly with time in the solvent extraction, but increased greatly with time in the steam distillation process (data not shown). The pattern of these individual monoterpenoids was similar to the pattern of total monoterpenoid concentration shown in Figure 1. The $\beta$-pinene and camphor were the only monoterpenoids which did not increase with time in either extraction technique. The concentrations of these compounds were only 
Table 1. Mean (SE) monoterpenoid concentration ( $\mathrm{mg} \mathrm{g}^{-1}$ fresh weight) and composition ( $\%$ ) in Ashe and redberry juniper after an 8 hour distillation and a 24 hour solvent extraction.

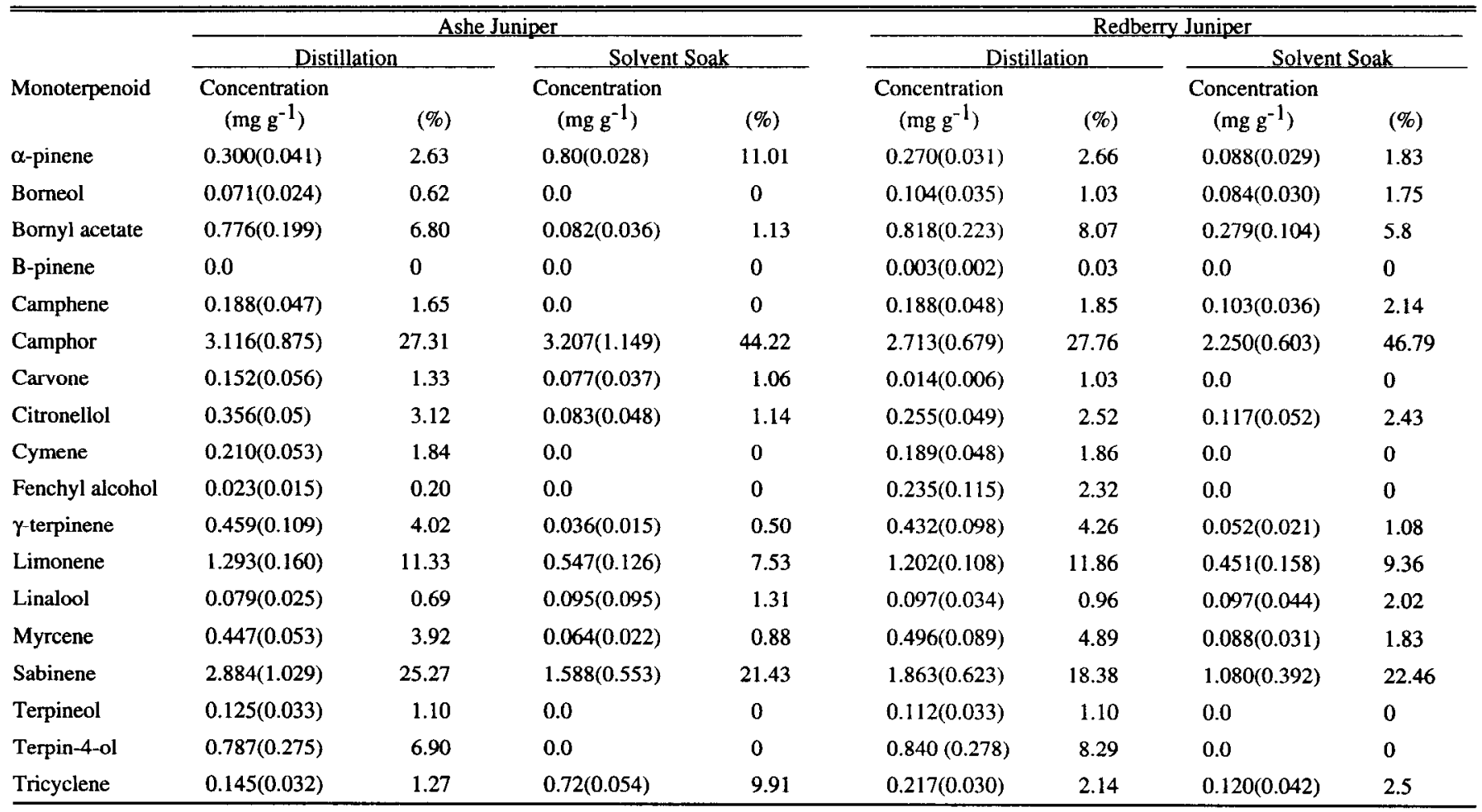

affected by the plant species, with Ashe juniper having greater concentration of camphor and redberry juniper having a slightly greater concentration of $\beta$-pinene (Table 1).

\section{Discussion}

Total monoterpenoid concentration of Ashe and redberry juniper was similar to concentrations in other coniferous trees. Monoterpenoid concentrations range from as little as $0.24 \mathrm{mg} \mathrm{g}^{-1}$ fresh weight in the needles of grand fir (Muzika et al. 1989) to as much as $11.37 \mathrm{mg} \mathrm{g}^{-1}$ fresh weight in Douglas fir (Pseudotsuga menziesii) (Zou and Cates 1994). Concentrations within single leaf pinyon (Pinus monophylla), a species which often grows in association with junipers, range from 4.95 to $6.16 \mathrm{mg} \mathrm{g}^{-1}$ fresh weight in different seasons of the year (Wilt et al.1991). Direct comparison with the literature reporting the presence of monoterpenoids in Juniperus species is difficult because typically only the composition of oils rather than the absolute amounts have been reported (Adams 1975, 1977, 1994). In the only other published report of monolerpenoid concentrations in these juniper species, Riddle et al.(1996) reported a range of 6.85 to $10.96 \mu \mathrm{g} \mathrm{g}^{-1}$ fresh needle weight. Obviously, our values are much greater than these previously reported values for Ashe and redberry juniper (by a factor of 1000) although we were working with the same population of trees. Data were recalculated in Riddle's study and should have been reported as $\mathrm{mg} \mathrm{g}^{-1}$ which would be comparable to the range of values reported for this study (Riddle, pers. comm.).

The optimum technique for extracting monoterpenoids has been shown to be species-specific (Muzika et al. 1990). In a com- parison of 5 extraction techniques ( 8 hour distillation with $2 \mathrm{~g}$ foliage, 8 hour distillation with $10 \mathrm{~g}$ foliage, solvent extraction, rapid steam distillation, and liquid $\mathrm{CO}_{2}$ extraction), Muzika et al. (1990) found that 8 hour distillation with $10 \mathrm{~g}$ of foliage yielded the most monoterpenoids with the least coefficient of variation from both blue spruce and grand fir needles. Solvent extraction using hexane yielded a similar amount of monoterpenoids as the distillation technique for blue spruce, but significantly less total terpenes for the grand fir. Solvent extractions have been used on many other species such as Douglas fir (Zou and Cates 1995), fir hybrids (Koedam et al. 1980) and single leaf pinyon pine (Pinus monophylla) (Wilt et al. 1991). We found that hexane solvent extraction always resulted in a lower estimate of total monoterpenoid concentrations and in a decreased diversity of the types of monoterpenoids regardless of the species of Juniperus. In our study, a 6-hour solvent soak, which was well within the range of published extraction times, resulted in the identification of only 3 monoterpenoids (camphor, limonene and sabinene). Increasing the soaking period to 24 hours increased the number of different monoterpenoids detected, but the total concentration was still significantly lower than from an 8 hour distillation (Table 1, Fig. 1). The differential solubilities of monoterpenoids may partially explain the observed results. Oxygen containing monoterpenoids, such as in a ketone like camphor, have solubilities of 10 to 100 times greater than other hydrocarbon monoterpenoids, such as cymene, myrcene, and $\gamma$-terpinene (Weidenhamer et al. 1993).

There have been several problems reported with using both steam distillation and solvent extraction to extract monoterpenoids from plants (Koedam 1987). First, some compounds may deteriorate from one form to another during the distillation process (e.g., sabinene may deteriorate into terpin-4-ol, a-ter- 


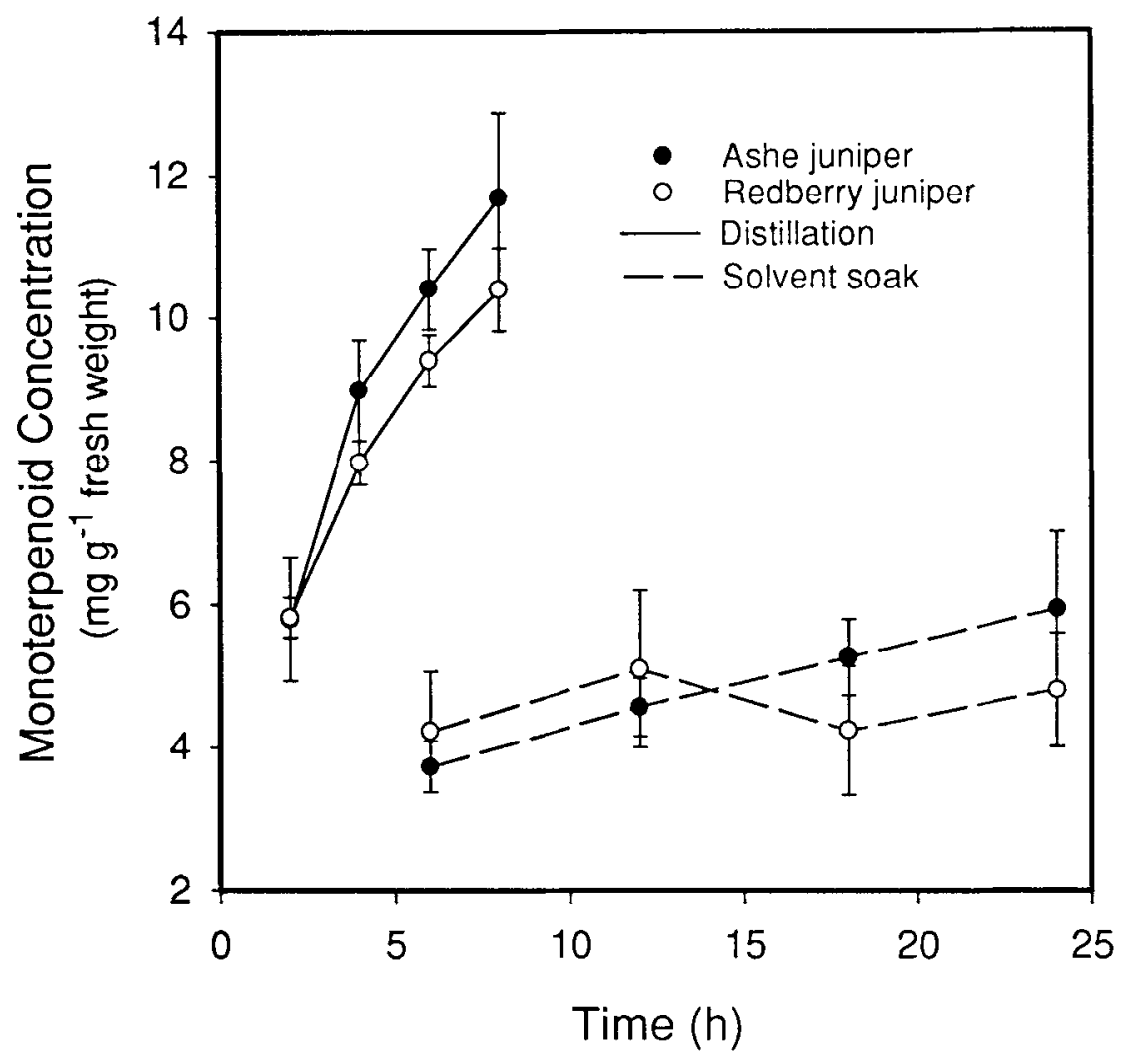

Fig. 1. Total monoterpenoid concentration ( $\mathrm{mg} \mathrm{g}^{-1}$ fresh weight) of Ashe and redberry juniper during an 8 hour distillation and a 24 hour solvent extraction period. Vertical bars represent $\pm S E, n=10$ for each point.

pinene, g-terpinene, and terpinolene). Terpin-4-ol and g-terpinene were detected in this study so it is possible that their presence is an artifact of the distillation process rather than representing their true occurrence in the plant. It is interesting to note, however, that the amount of sabinene increased in the steam distilled samples rather than decreasing due to breakdown (Table 1). Another reported problem is the crystallization of some compounds within the distillation condenser (Koedam 1987). Camphor and borneol are both susceptible to crystallization but we did not find a significant decrease in the concentration of either of these monoterpenoids from the solvent soak to the steam distillation extraction techniques. The third problem is that solvent soaking may result in chemical reactions with non- volatile compounds such as fatty oils, waxy materials, and flavinoids (Koedam 1987). These compounds are then included in the extracted sample and consequently more noise is evident in the chromatogram making peak identification much more difficult. We selected hexane as the solvent because it is less likely to extract these non-volatile compounds than other common solvents (acctone, ether, etc.).

There seem to be as many different gas chromatography methods as there are reports on monoterpenoid concentrations. Authors have used GC's with columns of fused silica (Gambliel and Cates 1995), 50\% carbowax-50\% methyl silicone (Muzika et al. 1989, Chang and Hanover 1991), wide bore, methyl-silicone coating (Wilt et al. 1993), as well as many others (Hall and Langenheim 1986, Kainulainen et al. 1992, Nerg et al. 1994). Each of the manuscripts cited above used a unique temperature program, injector port temperature and detector port temperature for their particular column. We found no significant differences in monoterpenoid composition or concentration between the 2 different types of GC columns tested. Although the column used in Sonora was $5 \mathrm{~m}$ longer and almost twice the diameter (.53 vs $.25 \mathrm{~mm}$ ) as the column used in Uvalde, the capillary columns yielded similar estimates of monoterpenoid concentrations.

\section{Conclusion}

In summary, an 8 hour steam distillation of juniper resulted in the greatest concentration and compositional diversity of monoterpenoids. Increasing distillation time from 2 to 8 hours greatly increased the total concentration of monoterpenoids. A solvent soak in hexane yielded significantly lower total concentrations of monoterpenoids and failed to extract some monoterpenoids present in trace amounts. The estimation of monoterpenoid concentration in Juniperus leaves was highly dependent on the technique used to extract the oils from the leaves, but was not affected by the analytical technique.

\section{Literature Cited}

Adams, R. P. 1975. Numerical-chemosystematic studies of infraspecific variation in Juniperus pinchotii. Biochem. Syst. and Ecol. 3:71-74.

Adams, R. P. 1977. Chemosystematics-analyses of populational differentiation and variability of ancestral and recent populations of Juniperus ashei. Ann. Missouri Bot. Gard. 64:184-209. 
Adams, R. P. 1994. Geographic variation and systematics of monospermous Juniperus (Cupressaceae) from the Chihuahua Desert based on RAPDs and terpenes. Biochem. Syst. and Ecol. 22:699-710.

Adams, R. P. and J. R. Kistler. 1991. Hybridization between Juniperus erythrocarpa Cory and Juniperus pinchotii Sudworth in the Chisos mountains, Texas. Southwestern Nat. 36:295-301.

Bray, R.O., C.L. Wambolt, and R.G. Kelsey. 1991. Influence of sagebrush terpenoids on mule deer preference. J Chem. Ecol 17:2053-2062.

Bryant, J. P., F. D. Provenza, J. Pastor, P.B. Reichardt, T.P. Clausen, and J.T. du Toit. 1991. Interactions between woody plants and browsing mammals mediated by secondary metabolites. Ann. Review of Ecol. and Syst. 22:431-446

Chang, J. and J. W. Hanover. 1991. Gengraphic variation in the monoterpene composition of black spruce. Can. J. Forest Res. 21:1796-1800.

Gambliel, H.A. and R.G. Cates. 1995. Terpene changes due to maturation and canopy level in Douglas-fir (Pseudotsuga menziesii) flush needle oil. Biochem. Syst. and Ecol. 23:469-476.

Gilmore, A. R. 1977. Effects of soil moisture stress on monoterpenes in loblolly pine. J. Chem.Ecol. 3:667-676.

Hachey, J. M. and S. Simard. 1987. Extraction and analysis of the essential oil of the needles and twigs of white spruce Picea glauca (Moench) Voss. J. Wood Chem. and Tech. 7:333-341.

Hall, G. D. and J. H. Langenheim. 1986. Within-tree spatial variation in the leaf monoterpenes of Sequoia sempervirens. Biochem. Syst. and Ecol. 14:625-632.

Kainulainen, P., J. Oksanen, V. Palomaki, J.K. Holopainen, and T. Holopainen. 1992. Effect of drought and waterlogging stress on needle monoterpenes of Picea abies. Can. J. Bot. 70:1613-1616.

Koedam, A. 1987. Some aspects of essential oil preparation. In: Sandra, P. and C. Bicchi (eds). Capillary gas chromatography in essential oil analysis. New York, N.Y.

Koedam, A., J. J. C. Scheffer, and A.B. Svendsen. 1980. Monoterpenes in the volatile leaf oil of Abies $x$ arnoldiana Nitz. J. Agric. Food Chem. 28:862-866.

Muzika, R. M., K. S. Pregitzer, and J.W. Hanover. 1989. Changes in terpene production following nitrogen fertilization of grand fir (Abies grandis (Dougl.) Lindl.) seedlings. Oecologia 80:485-489.
Muzika, R. M., C. L. Campbell, J.W. Hanover, and A.L. Smith. 1990. A comparison of techniques for extracting volatile compounds from conifer needles. J. Chem. Ecol. 16:2713-2722.

Nerg, A., P. Kainulainen, M. Vuorinen, and M. Hanson. 1994. Seasonal and geographical variation of terpenes, resin acids and total phenolics in nursery grown seedlings of Scots pine (Pinus sylvestris L.). New Phytologist 128:703-713.

Philpot, C. W. and R. W. Mutch. 1968. Flammability of herbicidetreated guava foliage. USDA Forest Serv. Res. Paper INT 54.

Riddle, R. R., C.A. Taylor, Jr., M.M. Kothmann, and J.E. Huston. 1996. Volatile oil contents of Ashe and redberry juniper and its relationship to preference by angora and spanish goats. J. Range Manage. 49:35-41.

SAS. 1988. SAS/STAT User's Guide (Release 6.03). SAS Inst. Inc., Cary, N.C.

Tarayre, M., J.D. Thompson, J. Escarre, and Y.B. Linhart. 1995. Intra-specific variation in the inhibitory effects of Thymus vulgaris (Labiatae) monoterpenes on seed germination.Oecologia 101:110-118.

von Edne, C.N. 1993. Repeated measures analysis: Growth and other time-dependent measures. p113-137. In: Scheiner, S.M. and J. Gurevitch (ed), Design and analysis of ecological experiments. Chapman and Hall, New York, N.Y.

Weidenhamer, J.D., F.A. Macias, N.H. Fischer, and G.B. Williamson. 1993. Just how soluble are monoterpenes? J. Chem. Ecol. 19:1799-1807.

White, C.S. 1994. Monoterpenes: Their effects on ecosystem nutrient cycling. J. Chem. Ecol.20:1381-1406.

Wilt, F. M., G. C. Miller, and R.L. Everett. 1991. Measurement of monoterpene hydrocarbon levels in vapor phase surrounding singleleaf pinyon (Pinus monophylla Torr \& Frem, Pinaceae) understory litter. J. Chem. Ecol. 19:1417-1428.

Wilt, F. M., G. C. Miller, R.L. Everett, and M. Hackett. 1993. Monoterpene concentrations in fresh, senescent, and decaying foliage of singleleaf pinyon (Pinus monophylla Torr. \& Frem.: Pinaceae) from the western Grcat Basin. J. Chcm. Ecol. 19:185-194.

Zou, J. and R. G. Cates. 1994. Role of douglas fir (Pseudotsuga menziesii) carbohydrates in resistance to budworm (Choristoneura occidentalis). J. Chem. Ecol. 20:395-405.

Zou, J. P. and R. G. Cates. 1995. Foliage constituents of Douglas fir (Pseudotsuga-menziesii(Mirb) Franco (Pinaceae) - their seasonal resistance and silviculture management. J. Chem.Ecol. 21:387-402. 